University of Nebraska - Lincoln

DigitalCommons@University of Nebraska - Lincoln

3-2008

\title{
A pilot study into the effects of X-ray and computed tomography exposure on the amplification of DNA from bone
}

\author{
Britta M. Grieshaber \\ Indiana University - Bloomington \\ Daniel L. Osborne \\ University of Nebraska - Lincoln, dosborne2@unl.edu \\ Alison F. Doubleday \\ Indiana University - Bloomington \\ Frederika A. Kaestle \\ Indiana University - Bloomington
}

Follow this and additional works at: https://digitalcommons.unl.edu/anthropologyfacpub

Part of the Anthropology Commons

Grieshaber, Britta M.; Osborne, Daniel L.; Doubleday, Alison F.; and Kaestle, Frederika A., "A pilot study into the effects of X-ray and computed tomography exposure on the amplification of DNA from bone" (2008). Anthropology Faculty Publications. 32.

https://digitalcommons.unl.edu/anthropologyfacpub/32

This Article is brought to you for free and open access by the Anthropology, Department of at DigitalCommons@University of Nebraska - Lincoln. It has been accepted for inclusion in Anthropology Faculty Publications by an authorized administrator of DigitalCommons@University of Nebraska - Lincoln. 


\title{
A pilot study into the effects of X-ray and computed tomography exposure on the amplification of DNA from bone
}

\author{
Britta M. Grieshaber, ${ }^{1}$ Daniel L. Osborne, ${ }^{2}$ Alison F. Doubleday, ${ }^{1}$ and Frederika A. Kaestle ${ }^{1}$ \\ ${ }^{1}$ Department of Anthropology, Indiana University, Bloomington, IN, USA \\ ${ }^{2}$ Department of Anthropology and Geography, University of Nebraska-Lincoln, \\ 810 Oldfather Hall, Lincoln, NE 68588-0368, USA \\ Corresponding author - D. L. Osborne, email dosborne2@unl.edu
}

\begin{abstract}
This research investigates the intersection of radiography and aDNA, two commonly used methods in bioarchaeology. The goal of this project was to investigate the effects of radiation on the ability to amplify DNA from bone. Bones $(n=124)$ from domestic pig (Sus scrofa) feet were randomly sorted into a control group and four treatment groups: (1) single exposure X-ray; (2) single exposure CT; (3) multiple exposures X-ray; and (4) multiple exposures CT. Number of PCR cycles required to amplify DNA in $100 \mathrm{bp}, 200 \mathrm{bp}$ and $400 \mathrm{bp}$ segments were used as a proxy for the amount of available DNA. In the $200 \mathrm{bp}$ CT sample, distal phalanges required significantly more amplification cycles than did the other bones and were removed from analysis. Results suggest that in general radiation exposure fragments DNA thereby decreasing the amount that is amplifiable. While these results are suggestive, further research is required to elucidate the degree to which radiation fragments DNA in archaeological specimens.
\end{abstract}

Keywords: aDNA, x-ray, CT, radiography, bioarchaeology

\section{Introduction}

In 1895, Wilhelm Roentgen discovered X-rays and their usefulness in "shadowing" bones, a discovery for which he was awarded the first Nobel Prize in Physics in 1901. Xrays are composed of electromagnetic energy created when electrons moving at a high speed are suddenly stopped (Adler and Carlton, 1999). This occurs in an X-ray tube, an evacuated glass tube with a positive (anode) and negative (cathode) electrode on either end (Gregory, 1999). When kilovolts $(\mathrm{kV})$ are applied to the cathode, electrons speed towards the opposite side of the tube, striking the anode with great force (Jefferies, 1999). An energy conversion takes place, resulting primarily in heat $(99 \%)$, but also in X-rays (1\%) (Callaway, 2003). The X-rays then pass out of the tube through a window, directing the primary beam towards the object of study (Jefferies, 1999).
The term "attenuation" refers to the reduction in the number of X-rays in a beam as it passes through matter (Carlton and Adler, 2001). Various tissues have different attenuation rates, with bone being seven times more likely to absorb X-rays than soft tissue (Bushong, 2001:172). This is, in part, how a radiograph is produced. Only the X-rays that pass all the way through an object and strike a layer of emulsion on the film will darken the otherwise white picture (Auger, 1999). Something that appears white or light gray on the film, such as tooth enamel, is more dense than a darker area nearby, such as the pulp cavity. A latent image is created by this energy transfer, but a visible image can be seen after chemically developing the film (Bushong, 2001).

Almost immediately after the development of this technology, clinical medicine adopted its use. It was shortly thereafter applied to anthropology with Petrie (1898) radiographic examination of ancient Egyptian mummies. Subse- 
quently, radiographic analysis of archaeological specimens, including human and faunal remains as well as artifacts, became commonplace. Radiographic imaging is used considerably in anthropological research for the determination or detection of disease, injury, sex, age at death, and craniofacial morphology (Russel et al., 1980). The use of radiographic methods in the analysis of bone is often considered beneficial as it preserves morphology and thus is perceived as a non-invasive and non-destructive procedure.

Like X-ray imaging, computed tomography (CT) scanning is used to a large extent in anthropological inquiries. CT was first developed by Allan Cormack in 1963, however, it was Sir Godfrey Newbold Hounsfield who designed the first commercial CT machine (Hounsfield, 1973). CT scans use X-rays, a detection system, and a computer to interpret the data into cross-sectional images. Every object or person undergoing a scan is exposed to a series of X-rays at different angles (Lewin et al., 1996). In spiral CT, the X-ray tube rotates continually around the subject, without reversing (Bushong, 2001). The X-rays are released through a narrow slit that controls the slice thickness of the scan. The detection system measures the attenuation rate (Wolbarst, 1999).

Multi-slice CT was developed in the early 1990s and requires several parallel detector arrays containing thousands of detectors to create a cross-sectional image of a body from the differences in tissue density (Slone, 2000). Once the attenuation rate is calculated, the data appear on a computer screen; black areas represent regions of lowest density, white areas represent regions of highest density (Spoor et al., 2000). These slices of data can then be stacked to provide a three-dimensional image for viewing or stereolithography (Hjalgrim et al., 1995). The crosssectional images from CT have an advantage over those of conventional radiography in that there is no "interference from structures lying on either side of the plane of interest" (Spoor et al., 2000:63). CT does, however, require a higher radiation dosage than traditional radiography.

As with X-ray imaging, CT scanning was introduced to the discipline of anthropology shortly after the technology was perfected. CT use in anthropology has many advantages over the use of conventional radiography; primarily that it is possible to view both soft and hard tissues as a three-dimensional image. This technology allows the specimen to be dissected electronically, even separating flesh from bone (Lewin et al., 1996:11). CT technology can also differentiate between the borders of a fossilized cranium and the stone matrix within it to estimate endocranial capacity (Conroy et al., 1990).

In anthropological research, Lewin and Harwood-Nash (1977) first employed the technique to examine the preserved brain of an adolescent Egyptian boy without undermining morphology. Since then, a wide range of anthropological investigations have utilized CT technology, including studies of dental development, dental root morphology, inner ear morphology, paranasal sinuses, new bone formation, anthropometry, stereolithographic modeling, and bone mineral density and geometry, to name a few (Chege et al., 1996; Chen and Lam, 1997; Lynnerup et al., 1997; Spoor et al., 2000; Zonneveld et al., 1989]).
These techniques, however, were initially adopted and incorporated into anthropological studies before analysis of ancient DNA became commonplace within the field. Most investigators, therefore, conducted research without consideration for the potential interaction between the use of radiography on human and faunal remains, and the extraction and amplification of ancient DNA (aDNA) from those remains.

Ancient DNA analysis has only recently become a widely used method in anthropology due to the advent of the polymerase chain reaction (PCR) in the late 1980s (Mullis and Faloona, 1987). This procedure allows small fragments of DNA, in low concentrations, to be amplified quickly. Immediately after its development, researchers in anthropology adopted the technique in order to explore questions of genetic diversity across time and place. The anthropological applications of aDNA research, as reviewed by such researchers as Kaestle and Horsburgh (2002) and O'Rourke et al. (2000), include examining human origins and behavior at individual and population levels. aDNA research can address questions about population movements, social structure, marriage patterns, diet, disease, and mortuary practices and may provide a different viewpoint from more traditional archaeological methods.

Amplification of DNA from ancient samples, however, can be difficult and is often complicated by handling, storage and treatment of the specimen after excavation. In particular, there is some concern over the effects of radiation on DNA preserved in ancient samples. Radiation fragments DNA and while living organisms can repair the damage, this mechanism ceases upon death. Further, ancient specimens are usually already degraded due to natural processes such as oxidation and hydrolysis, which are dependent on the presence of water, soil $\mathrm{pH}$, and radiation from the environment (Eglington and Logan, 1991; O'Rourke et al., 2000; MacHugh et al., 2000; Burger et al., 1999). The amplification of DNA from ancient samples may be further affected by controlled radiography. This issue, however, has not been explored to an adequate degree.

Traditionally, in the anthropological literature, radiographic procedures are seen as non-destructive because there is no apparent damage to the specimen. Gray, for example, in a review of radiography use in analyzing mummies, stated, "radiography has no deleterious effect on a wrapped mummy ..." (Gray, 1967:34). This has, unfortunately, become the standard assumption and this attitude has carried over into CT studies. For instance, Magid and colleagues felt that "CT permits an ideal, nondestructive analysis" (Magid et al., 1989:239). Melcher et al., (1997; p. 336) even went as far to say "CT should be used in preference to all of the other methods presently available for examining mummies." The view of Lewin et al. (1996) seems unique in that they acknowledged repeated X-ray exposure of Ramses II (to prevent fungal infection) caused molecular damage, and prevented any chemical or DNA analysis. Still they do recommend, "all biological material should be X-rayed prior to examination" (Lewin et al., 1996; p. 12).

Muller (1927) was the first to identify a negative impact of radiation on genetic material. "In addition to the gene 
mutations, it was found that there is also caused by X-ray treatment a huge proportion of rearrangements in the linear order of the genes" (Muller, 1927; p. 85). Others have shown that radiation breaks DNA into fragments and causes base-change mutations (Wolff, 1971; Liber et al., 1986; Grosovsky et al., 1988).

Ionizing radiation can cause changes in the atomic structure of molecules if it is absorbed by matter (Jefferies, 1999). This occurs through a direct or indirect manner, and the two do occasionally happen to the same molecule. In the direct effect, an X-ray photon hits a DNA molecule, is absorbed, and then excites the atoms to a higher energy level. Excess energy is released, destabilizing the molecule (Jefferies, 1999). An indirect hit occurs when a free radical from the surrounding environment (usually water) becomes ionized by radiation exposure and then transfers that energy (an unpaired electron) to a DNA molecule. The addition of the high-energy electron to the DNA molecule creates a point lesion (Bushong, 2001). These breaks in the bases or phosphate bonds result, in a living cell, in the rearrangement or loss of genetic information (Jefferies, 1999).

The majority of damage in short segments of DNA consists of simple strand breaks (Nikjoo and Charlton, 1995). A double strand break will occur if two or more radical pairs occur within a nanometer-sized volume, and they react with the DNA on opposite strands (Ward et al., 1995). These strand breaks occur when a primary radical is formed at the sugar molecule of DNA or when a nucleic acid base radical transfers the damage to the sugar molecule involving a hydrogen abstraction reaction (Melvin et al., 1995).

Living organisms can withstand moderate levels of radiation because of DNA restoration through recombination, restitution, and repair (Alpen, 1998). Also, a cell may cease to function but can be replaced by another functioning copy, ensuring the survival of the affected tissue. Deceased individuals, however, do not have functioning repair enzymes. Therefore, when a DNA strand breaks, it generally remains broken. If several double strand breaks occur, the DNA will be fragmented into short segments. These smaller fragments may be insufficient for amplification or other types of genetic analyses. Ancient DNA is generally already fragmented by several processes, and the addition of intentional radiation may damage the DNA to a point at which it is unrecoverable for analysis.

To date, only Gotherstrom et al. (1995) have investigated the effect of radiation exposure on subsequent DNA retrieval and analysis. Although their results were preliminary, the authors showed that the normal level of radiation from X-rays used on archaeological samples does degrade available DNA. If too high a dose is used, PCR amplification of even relatively short DNA fragments becomes impossible. A literature search indicates that no one has examined the effects of CT exposure on ancient DNA, and even Gotherstrom et al. (1995) suggest that more in-depth study of X-ray effects on aDNA is necessary.

The research presented herein further addresses this issue by investigating the amplification of DNA from bone exposed to X-ray and CT. We hypothesize that DNA from bone that has been exposed to clinical radiation will be sig- nificantly more difficult to amplify than DNA from a control sample that has not been exposed to radiation. These results will have an impact on aDNA studies, as well as on osteological examinations of archaeological remains.

\section{Materials and methods}

Archaeological samples were not used due to the need for large numbers of skeletal elements from the same species, recovered from the same time period, and exposed to the same degradative processes. The latter concern was paramount, as previous research and the authors' personal experience suggest that small differences in depositional characteristics can have major effects on the preservation of DNA, even within remains recovered from a single site (e.g., Burger et al., 1999; Collins et al., 2002). Therefore, bones from nine Sus scrufa (common domestic pig) feet were used as a proxy for archaeological bone. The skin, muscles, tendons, and ligaments of each foot were removed using a scalpel. Each foot was processed using separate razors to prevent cross contamination of DNA among samples.

For each of the nine Sus scrufa feet, four bones (two metapodials, a terminal/distal phalanx, and a mediumsized podial such as the cuboid or one of the cuneiforms) were held as controls and not exposed to any radiation $(n=36)$. Four bones from each foot (a proximal phalanx, a terminal phalanx, a metapodial and a medium-sized podial) were placed into an experimental group exposed to X-ray at $60 \mathrm{kVp}, 200 \mathrm{~mA}$, for $27 \mathrm{~ms}(7 \mathrm{~mA} \mathrm{~s})$, at $101 \mathrm{~cm} \mathrm{(40}$ inches) distance $(n=36)$. Further, four additional podials were $\mathrm{X}$-rayed under the same parameters three times to assess the effects of multiple X-ray exposure $(n=4)$.

An additional four bones from each foot (a proximal phalanx, a metapodial, a large podial such as the calcaneum, astragalus, or navicular, and a medium-sized podial) were placed in an experimental group exposed to CT (GE) at $120 \mathrm{kV}, 140 \mathrm{~mA} \mathrm{~s}$ in $2 \mathrm{~mm}$ slices with a neutral filter $(n=36)$. These parameters were established by staff at Bloomington Hospital. An additional nine bones (three terminal phalanges, three metapodials, three podials and three proximal phalanges) were exposed to the same CT parameters three times so that the effects of multiple exposures could be examined $(n=9)$. Modifications in which bone was included in each group did occur, because of the absence or unsuitability of various individual bones. For example, in the control group, the terminal phalanges for pigs 5 and 8 were not suitable for analysis due to fracturing during the boiling process so a proximal phalanx was used instead. The final sample size was 124 skeletal elements.

All samples, including controls, were decontaminated of exogenous DNA by exposing the surface of the bone to UV light for $5 \mathrm{~min}$ on each side in a Crosslinker $(120,000 \mu \mathrm{J} /$ $\mathrm{cm}^{2}$ ). Cortical bone protects the endogenous DNA from UV radiation, therein eliminating the possibility of UV damage to the endogenous DNA contained in the bone. For samples exposed to X-ray or CT, decontamination of exogenous DNA took place after radiation exposure. The bone 
was then crushed between UV irradiated weigh boats with a bleached hammer, and $0.46-0.54 \mathrm{~g}$ of bone were placed in UV irradiated $15 \mathrm{ml}$ sterile polypropylene tubes. Next, $1.9 \mathrm{ml}$ of molecular grade $0.5 \mathrm{M}$ EDTA, $\mathrm{pH} 8.0$ were added to each tube and the cap sealed with parafilm. The samples were then rocked at room temperature for approximately $24 \mathrm{~h}$. After $24 \mathrm{~h}$, the used EDTA was removed, discarded and fresh EDTA added. To prevent contamination, the pipette barrel was bleached between samples. After another $24 \mathrm{~h}$, the above procedure was repeated, including a change of the EDTA. DNA was extracted, from this final batch of EDTA only, using a standard phenol/chloroform protocol, and the resulting extract concentrated through centrifugal filtrations using a Centricon ${ }^{\circledR} 100$ centrifugal filter unit (Millipore). Extracts were stored at $-80^{\circ} \mathrm{C}$ until amplification by PCR. Aliquots of EDTA and proteinase-K were taken through the same extraction protocol to act as negative controls and to ensure that contamination was not introduced into the extraction procedure.

Amplification and quantification took place using the iCycler iQ ${ }^{\mathrm{TM}}$ Multi-Color Real-time PCR Detection System (BioRad). Real-time PCR uses a fluorescent detection strategy to identify the amplification of DNA during each cycle. For these experiments, SYBR Green ${ }^{\odot}$, a dye that binds with double stranded DNA and fluoresces when excited by a laser (Walker, 2002) was used. The BioRad system simultaneously illuminates and records data from all 96 wells under analysis, allowing for reliable comparison between wells. The amount of DNA present in a sample, and its threshold detection cycle, is measured through this fluorescence because the amount of emitted fluorescence is proportional to the amount of amplified DNA (Klein, 2002).

Primers were designed to amplify 100 base pair (bp), $200 \mathrm{bp}$, and $400 \mathrm{bp}$ segments of mtDNA and were checked for secondary structure and primer-dimer formation using the Oligo Analyzer 3.0 and mFold software available on the Integrated DNA Technologies (IDT) website: http:// biotools.idtdna.com/gateway/. A BLAST search of the GenBank database (Benson et al., 2002; Altschul et al., 1990) confirmed that these primers would amplify only Sus scrufa DNA, and in particular would not amplify human DNA. Primers used: P15852 forward (5'-GAC AAA GCA ACC CTC ACA CGA TTC-3') and P15952 reverse (5'-CGG TTT CGT GCA GGA ATA GGA GAT-3'), P4554 forward (5'TAA CGT AGA ATA TGC AGC CGG ACC-3') and P4759 reverse (5'-ATC GTG GGT ATG ATG CTC GGA TTC-3'), and P11984 forward (5'-TGT ACG GAC TCC ATC TTT GAC TGC-3') and P12391 reverse (5'-CCA GGA TTA TGG TTC GGC TGT GTA-3'). An optimization run, using DNA from Sus scrufa muscle tissue, determined the appropriate annealing temperature for all primer pairs was $60^{\circ} \mathrm{C}$.

PCR set up occurred in a PCR isolation chamber inside the IUB Ancient DNA Laboratory, following standard aDNA protocols (see Kaestle and Horsburgh, 2002) using aerosol-resistant filter tips, calibrated pipettes, and PCRgrade water. A BioRad Super IQ Master Mix with SYBR Green containing optimized concentrations of Taq, $\mathrm{MgCl}_{2}$, dNTPs, and a proprietary buffering system was used, for a total volume of $25 \mu \mathrm{l}$ per tube. Final primer concentrations were $0.24 \mu \mathrm{M}$, and $1 \mu \mathrm{l}$ of DNA extract was used as a template. Each sample was amplified in triplicate for each amplification run and the results averaged to limit the effect of outliers on the study results. In addition to the extractions from the bone samples, negative controls of EDTA, proteinase- $K$, and the amplification master mix were used to test for contamination of the extracts and the PCR reaction. EDTA and proteinase-K controls had been taken through the same extraction protocol as the skeletal samples.

An initial attempt at amplification, using the iCycler $\mathrm{iQ}^{\mathrm{TM}}$ Multi-Color Real-time PCR Detection System (Bio$\mathrm{Rad})$, followed a three-cycle protocol. Cycle one held the samples at $95^{\circ} \mathrm{C}$ for $3 \mathrm{~min}$ to ensure complete denaturation and activate the DNA polymerase. Cycle two, step one held the samples at $95^{\circ} \mathrm{C}$ for $30 \mathrm{~s}$, and step two lowered the temperature to $60^{\circ} \mathrm{C}$ for $30 \mathrm{~s}$, to amplify the targeted region of DNA. This cycle was repeated forty times. The third cycle held the samples at $4{ }^{\circ} \mathrm{C}$ until removed from the machine. Samples included in this initial attempt were the CT phalanx and the control terminal phalanx from each pig foot $(n=18)$. All other samples followed the same protocol for the first two cycles, but cycle three held the samples at $95^{\circ} \mathrm{C}$ for $1 \mathrm{~min}$ in preparation for the creation of a melt curve. An additional cycle (cycle four) decreased the set point temperature by $1{ }^{\circ} \mathrm{C}$ every minute 70 times to produce a melt curve. The last cycle (cycle five) held the samples at $4{ }^{\circ} \mathrm{C}$ until removed from the machine.

Initial results from the real-time PCR were unclear. Although all samples were amplified in triplicate, there were several intra-sample inconsistencies with regard to the cycle at which DNA was detectable. To clarify realtime PCR results and to determine if DNA was, in fact, present in the samples standard PCR reactions were also run for the following samples: all control terminal phalanges, all X-ray terminal phalanges, all control podials, all CT podials, all control metapodials, all control thin metapodials, all CT metapodials, all CT phalanges, and all Xray phalanges (total $n=81$ ). The PCR setup occurred inside the Ancient DNA Laboratory following standard lab protocol. The reactions were performed in a $25 \mu \mathrm{l}$ volume, and included 1.5 Units of platinum Taq (Invitrogen), $0.24 \mu \mathrm{M}$ primers, and $1.5 \mu \mathrm{M} \mathrm{MgCl}_{2}$. Negative amplification controls were also included for EDTA, proteinase-K and PCR Master Mix, as well as a positive control consisting of a sample of DNA from Sus scrufa muscle tissue (this control DNA was added to the tube in a separate Modern DNA Laboratory, where all PCR amplification and postPCR analyses took place). The PCR protocol held the samples at $95^{\circ} \mathrm{C}$ for $3 \mathrm{~min}$, ran $35-45$ cycles of denaturing at $95^{\circ} \mathrm{C}$ for $30 \mathrm{~s}$, annealing at $60^{\circ} \mathrm{C}$ for $30 \mathrm{~s}$, and extending at $72^{\circ} \mathrm{C}$ for $1 \mathrm{~min}$. The reaction was then held at $4{ }^{\circ} \mathrm{C}$. Products from the standard PCR were then electrophoresed on a $2 \%$ agarose gel. The presence or absence of a band was used to determine presence or absence of amplified DNA. No bands were detected for any samples, although many blurry smears were evident.

After standard PCR also failed to demonstrate adequate DNA in the samples (including controls), the investigators decided to test for PCR inhibitors. An amplification was set 
up, including extract from skeletal samples as usual, but with the addition of $1 \mu \mathrm{l}$ of issue-derived pig DNA to each tube. Because the modern DNA consistently amplified successfully, failure of the issue-derived DNA to amplify, when added to the DNA extracted from the experimental groups, would indicate the presence of PCR inhibitors. Once again, no samples amplified, suggesting a problem with PCR inhibition.

To remove inhibitors, all samples used in the standard PCR $(n=81$, samples listed earlier) were cleaned using a Qiagen QIAquick PCR Purification Kit (Qiaquick Spin Handbook, 2002). Standard PCR was conducted again and electrophoresis confirmed the presence of DNA. The Qiagen kit binds DNA to silica particles and is designed to allow inhibitors to be washed away. Interestingly, it also only allows for $10 \mu \mathrm{g}$ of DNA to bind to the silica in the membrane. All excess DNA washes through with the rest of the discarded material. Therefore, the concentration of DNA after purification with the Qiagen kit will be reduced in comparison to that of the original extractions.

Although exact $n g / \mu l$ of DNA for each sample was not calculated, these results suggest that the original problems in amplification may have been due to DNA overload. Overload occurs because there is so much DNA present that the primers are exhausted early in the process and amplification products begin to anneal to themselves. In electrophoresis, overload appears as smears on a gel. The smears detected on the gels in this study are similar to examples of DNA overload put forth by Hummel (2003:64). The problem of excess DNA is not common in aDNA studies and was not considered to be a potential hazard early on. It is important to remember, however, that the samples used in this study came from fresh bone and, most likely, contained a higher DNA concentration than skeletal remains from an archaeological assemblage. To combat problems arising from DNA overload, DNA extractions from all bones were diluted with molecular grade water for a final DNA to water ratio of 1:10. Real-time PCR was then used to amplify the diluted DNA.

Using the real-time PCR machine, the number of cycles required to amplify DNA was quantified and used as the outcome variable. Since PCR duplicates DNA sequences, theoretically the amount of DNA copies accumulated after each cycle is dependent on the starting number of copies of the target sequence. This analysis assumes that the number of cycles necessary for amplification detection is a reflection of available DNA in the specimen.

Because the samples used were extracted from modern bone and because of initial problems with DNA overload, we were also confident that the DNA template was of relatively high quantity. Standard PCR protocols indicate that 25-30 cycles of PCR are typically adequate for amplification of DNA of high quantity. Based on this assumption, we concluded that if a sample were to reach 30 PCR cycles (using the real-time PCR machine) with no detectable amplification, then insufficient DNA is available. In this sense, a value of 30 cycles is no different from 35 cycles. Thus, any specimen producing cycle values over this limit were reduced to 30 in the subsequent analysis to prevent inflation of group means. Differences in amplification time between
$100 \mathrm{bp}, 200 \mathrm{bp}$ and $400 \mathrm{bp}$ groups were compared as were differences between bone types and the control and treatment groups. The number of cycles necessary to reach amplification were tested using ANOVA with Bonferroni correction for pairwise comparisons $(a=0.05)$.

\section{Results}

None of the $400 \mathrm{bp}$ specimens amplified within 30 PCR cycles and thus were removed from further analysis. This is not entirely unanticipated, as DNA degradation occurs quickly after death and even un-irradiated modern bones are likely to contain fragmented DNA that is very difficult to amplify when large amplicons are targeted.

The distal phalanges required significantly more amplification cycles than the other bones in the $200 \mathrm{bp}$ CT treatment group $(p \leq 0.004)$. These amplification data derived from distal phalanges were excluded from further analysis in this particular group so as to not bias the results.

The descriptive statistics are provided in Table 1. As was anticipated, the mean amplification values of the specimens exposed to a single radiation event are higher than the control group in both the $100 \mathrm{bp}$ and $200 \mathrm{bp}$ groups (i.e., they require more amplification cycles before a signal of successful amplification is detected). However, in both groups the mean values from the treatment groups exposed to radiation multiple times are lower than expected relative to their control and single exposure counterparts. This is possibly a reflection of their disparate sample sizes. Kolmogorov-Smirnov tests confirmed that neither of the sub-samples departed significantly from a normal distribution. Also, Levene's tests confirmed that the variances of these groups were all equal.

Not surprisingly, the mean amplification values of the $200 \mathrm{bp}$ sub-sample are higher than the $100 \mathrm{bp}$ specimens reflecting the ease at which shorter sequences are amplified from fragmented template DNA, although these differences are not statistically significant. If the data from the phalanges are included in the analysis then the time to amplification detection of the $200 \mathrm{bp}$ CT group is significantly

Table 1. Descriptive statistics

\begin{tabular}{llrcc}
\hline Amplified fragment & Treatment & $n$ & Mean & SD \\
\hline $100 \mathrm{bp}$ & Control & 31 & 18.5 & 3.1 \\
& X-ray & 30 & 18.9 & 1.8 \\
& CT & 35 & 19.8 & 2.5 \\
& Multi-X-ray & 4 & 18.6 & 1.1 \\
& Multi-CT & 12 & 20.5 & 2.4 \\
& Total & 112 & 19.2 & 2.5 \\
& & & \\
& Control $\mathrm{bp}$ & 36 & 19.1 & 3.0 \\
& X-ray & 30 & 19.5 & 2.3 \\
& CT & 26 & 19.5 & 2.2 \\
& Multi-X-ray & 4 & 18.8 & 0.9 \\
& Multi-CT & 12 & 21.0 & 2.6 \\
& Total & 108 & 19.6 & 2.6 \\
\hline
\end{tabular}

Mean refers to mean number of cycles required to detect amplification of DNA; $n$ refers to number of skeletal samples from which DNA was extracted. 
greater than that of the controls. However, once Bonferroni correction is applied to the data all pairwise comparisons fail to achieve significance in both the $100 \mathrm{bp}$ and $200 \mathrm{bp}$ sub-samples.

\section{Discussion}

Interestingly, DNA was more difficult to amplify in the phalanges in the $200 \mathrm{bp}$ CT treatment group. This could be the result of many things, including sampling error. But it is possible that the DNA in these particular bones was subjected to greater degradation. Relative to the other bones used in this analysis the phalanges have a high surface to volume ratio which would make them more prone to changes in temperature, such as occurred during boiling, potentially degrading DNA more than those bones with a smaller surface to volume ratio. Furthermore, if radiation is fragmenting DNA, the degree of exposure will likely be influenced by bone density.

In this analysis there is no statistical evidence that exposure to radiation decreases the amount of amplifiable DNA. Unlike the results produced by Gotherstrom et al. (1995), X-ray exposure did not have a significant effect on amplification time in either the $100 \mathrm{bp}$ or $200 \mathrm{bp}$ groups regardless of the length of exposure. However, it is important to note that the amplicon size used by Gotherstrom et al. was appreciably longer at approximately $390 \mathrm{bp}$ (12S amplicon) and $510 \mathrm{bp}$ (16S amplicon). The amount of radiation emitted by CT is greater than standard X-ray, thus if radiation does decrease amplifiable DNA then it is likely that there would be a dosage effect. This may explain why the X-ray treatment was not significantly different from the control, as the amount of radiation might have been insufficient to produce an effect. However, neither of the multiple exposure treatments had a significant effect on amplification time in the $100 \mathrm{bp}$ and $200 \mathrm{bp}$ groups. The results of the multiple exposure treatment groups may be due to insufficient sample size and warrant further investigation. Despite the fact that none of the treatment groups differed significantly from the control, most of the treatment groups took longer to amplify than the respective control groups, suggesting that radiation exposure is further fragmenting the DNA.

The inability to amplify the $400 \mathrm{bp}$ segments is common in aDNA studies. In order to amplify such a large segment, DNA must be in good condition. The fact that none of the specimens used in this analysis were amplified at $400 \mathrm{bp}$ suggests that the skeletal material used adequately approximated the condition of archaeological bone. This may reflect the fact that DNA begins to degrade immediately after death, but may also reflect the use of boiling water and drying during tissue processing. Because the specimens used herein were exposed to boiling water for equal amounts of time, this should not be considered a confounding variable. However, if water molecules damage DNA, then radiation may not be a big problem in ancient tissues, especially in mummified material. Future studies may find it helpful to calculate the exact amount of DNA present for each sample for comparison with authentic aDNA samples.
These results suggest that exposure of bone to clinical levels of radiation decreases the amount of amplifiable DNA. This suggests that radiographic analysis of archaeological specimens may hinder future application of aDNA. This is not to say that radiographic analysis of specimens should be discontinued, as the results of this analysis could be argued to support a non-significant relationship between radiation exposure and DNA fragmentation. Rather, we suggest that, pending further analysis of the influence of radiation on DNA, steps should be taken to ensure the retrieval of tissue for aDNA analysis prior to exposure to radiation. These results warrant further large-scale studies, building upon the evidence presented herein. Also, early radiographic studies of anthropological material generally utilized older X-ray machines and may have exposed samples to higher levels of radiation. Thus, careful consideration of radiographic history of valuable samples should be undertaken before destructive aDNA analyses are initiated.

Future research investigating the effects of radiation on the amplification of DNA from bone may do well to consider other factors in research design. For instance, it would be interesting to examine how different elements differentially preserve DNA. If cortical thickness protects DNA from further degradation, then it would be necessary to stratify the experiment and control groups with equal numbers of the same bone. Also, the effects of radiographic procedures with minimal radiation exposure (e.g., dual Xray absorptiometry) should also be considered. Future research would also be benefit from quantification of $\mathrm{ng} / \mu \mathrm{l}$ for all samples and inclusion of equal and sufficient sample sizes for all treatment levels.

\section{Acknowledgments}

We would like to thank the Radiology staff at Bloomington Hospital, especially Bruce Riley, Cheri Stoute, Kent London and Tina Meeks for their time and resources. Thanks also to Mark Braun, Paul Jamison, Jennifer Raff, and the anonymous reviewers for Journal of Archaeological Science for helpful comments. Funding for this research was provided by internal research support from IUB to FAK.

\section{References}

Alpen, 19984 E. L. Alpen, Radiation Biophysics (second ed. ), Academic Press, San Diego, CA (1998).

Altschul et al., $1990<$ S. F. Altschul, W. Gish, W. Miller, E. W. Myers, and D. J. Lipman, Basic local alignment search tool, Journal of Molecular Biology 215 (1990), pp. 403-410.

Benson et al., 20024 D. A. Benson, I. Karsch-Mizrachi, D. J. Lipman, J. Ostell, B. A. Rapp, and D. A. Wheeler, GenBank, Nucleic Acids Research 30 (2002), pp. 17-20.

Burger et al., $19994 \mathrm{~J}$. Burger, S. Hummel, B. Herrmann, and W. Henke, DNA preservation: a microsatellite-DNA study on ancient skeletal remains, Electrophoresis 20 (1999), pp. 1722-1728. 
Bushong, 2001 S. C. Bushong, Radiologic Science for Technologists: Physics, Biology and Protection (seventh ed. ), Mosby, St. Louis, MO (2001).

Chege et al., $1996 \varangle$ N. Chege, D. J. Sartoris, R. Tyson, and D. Resnick, Imaging evaluation of skull trepanation using radiography and CT, International Journal of Osteoarchaeology 6 (1996), pp. 249-258.

Chen and Lam, $1997<$ X. Chen and Y. M. Lam, Technical note: CT determination of the mineral density of dry bone specimens using the dipotassium phosphate phantom, American Journal of Physical Anthropology 103 (1997), pp. 557-560.

Collins et al., 20024 M. J. Collins, C. M. Nielsen-Marsh, J. Hiller, C. I. Smith, and J. P. Roberts, The survival of organic matter in bone: A review, Archaeometry 44 (2002), pp. 383-394.

Conroy et al., 1990 G. C. Conroy, M. W. Vannier, and P. V. Tobias, Endocranial features of Australopithecus africanus revealed by 2- and 3-D computed tomography, Science 247 (1990), pp. 838-841.

Gotherstrom et al., 1995 A. Gotherstrom, C. Fischer, and $\mathrm{K}$. Linden, X-raying ancient bone: a destructive method in connection with DNA analysis, Laborativ Arkeologi 8 (1995), pp. 26-28.

Gray, 19674 P. H. K. Gray, Radiography of ancient Egyptian mummies, Medical Radiography and Photography 43 (1967), pp. 34-44.

Grosovsky et al., 1988 A. J. Grosovsky, J. G. de Boer, P. J. de Jong, E. A. Drobetsky, and B. W. Glickman, Base substitutions, frameshifts, and small deletions constitute ionizing radiation-induced point mutations in mammalian cells, Proceedings of the National Academy of Sciences USA 85 (1988), p. 185.

Integrated DNA Technologies 4 Integrated DNA Technologies website, http://biotools.idtdna.com/gateway/

Jefferies, $19994 \mathrm{~K}$. Jefferies, Basic radiation protection and radiobiology. In A. M. Adler and R. R. Carlton, eds., Introduction to Radiography and Patient Care (second ed. ), WB Saunders Company, Philadelphia, PA (1999), pp. 98-116.

Kaestle and Horsburgh, $2002<$ F. A. Kaestle and K. A. Horsburgh, Ancient DNA in anthropology: methods, applications and ethics, Yearbook of Physical Anthropology 45 (2002), pp. 92-130.

Klein, 20024 D. Klein, Quantification using real-time PCR technology: Applications and limitations, Trends in Molecular Medicine 8 (2002), pp. 257-260.

Lewin and Harwood-Nash, 1977 P. K. Lewin and D. C. Harwood-Nash, X-ray computed axial tomography of an ancient Egyptian brain, IRCS Medical Science: Anatomy and Human Biology: Biomedical Technology: Nervous System $\mathbf{5}$ (1977), p. 78.

Lewin et al., 19964 P. K. Lewin, J. E. Trogadis, and J. K. Stevens, Three-dimensional reconstruction from serial X-ray tomography of an Egyptian mummified head, Clinical Anatomy 3 (1996), pp. 215-218.

Liber et al., 19864 H. L. Liber, P. M. Leong, V. H. Terry, and J. B. Little, X-rays mutate human lymphoblast cells at genetic loci that should respond only to point mutagens, $\mathrm{Mu}$ tation Research 163 (1986), p. 91.
Lynnerup et al., $1997 \varangle$ N. Lynnerup, H. Hjalgrim, L. R. Nielsen, H. Gregersen, and I. Thuesen, Non-invasive archaeology of skeletal material by CT scanning and threedimensional reconstruction, International Journal of Osteoarchaeology 7 (1997), pp. 91-94.

Magid et al., 19894 D. Magid, B. Bryan, R. Drebin, D. Ney, and E. K. Fishman, Three dimensional imaging of an Egyptian mummy, Clinical Imaging 13 (1989), pp. 239-240.

Melcher et al., 1997 A. H. Melcher, S. Holowka, M. Pharoah, and P. K. Lewin, Non-invasive computed tomography and three-dimensional reconstruction of the dentition of a 2,800-year-old Egyptian mummy exhibiting extensive dental disease, American Journal of Physical Anthropology 103 (1997), pp. 329-340.

Melvin et al., $1995<$ T. Melvin, M. A. Plumb, S. W. Botchway, P. O'Neill, and A. W. Parker, The distribution of single strand breakage at guanine initiated by $193 \mathrm{~nm}$ light is different for single and double stranded DNA. In A. F. Fuciarelli and J. D. Zimbrick, eds., Radiation Damage in DNA: Structure/Function Relationships at Early Times, Battle Press, Columbus, OH (1995), pp. 175-184.

Muller, 1927 H. J. Muller, Artificial transmutation of the gene, Science 66 (1927), pp. 84-87.

Mullis and Faloona, $1987 \leftarrow$ K. B. Mullis and F. A. Faloona, Specific synthesis of DNA in vitro via a polymerase catalyzed chain reaction, Methods in Enzymology 155 (1987), pp. 335-350.

Nikjoo and Charlton, $1995 \varangle$ H. Nikjoo and D. E. Charlton, Calculation of range and distributions of damage to DNA by high- and low-LET radiations. In A. F. Fuciarelli and J. D. Zimbrick, eds., Radiation Damage in DNA: Structure/ Function Relationships at Early Times, Battle Press, Columbus, OH (1995), pp. 29-42.

O'Rourke et al., $2000<$ D. H. O'Rourke, M. G. Hayes, and S. W. Carlyle, Ancient DNA studies in physical anthropology, Annual Review of Anthropology 29 (2000), pp. 217-242.

Petrie, $1898<$ W. M. F. Petrie, Deshasheh 1897. Fifteenth Memoir of the Egypt Exploration Fund, Egypt Exploration Fund, London (1898).

Russel et al., $1980 \varangle$ W. Russel, A. Storey, and P. Ponitz, Radiographic techniques in the study of the mummy. In J. E. Harris and E. F. Werte, eds., An X-Ray Atlas of the Royal Mummies, University of Chicago Press, Chicago, IL (1980), pp. 163-187.

Spoor et al., $2000<$ C. F. Spoor, N. Jeffery, and F. Zonneveld, Using diagnostic radiology in human evolutionary studies, Journal of Anatomy 197 (2000), pp. 61-76.

Walker, 20024 N. J. Walker, A technique whose time has come, Science 296 (2002), pp. 557-559.

Ward et al., 1995 J. F. Ward, J. R. Milligan, G. D. D. Jones, and R. C. Fahey, Multiply damaged sites. In A. F. Fuciarelli and J. D. Zimbrick, eds., Radiation Damage in DNA: Structure/Function Relationships at Early Times, Battle Press, Columbus, OH (1995), pp. 45-54.

Wolff, $1971 \triangleleft$ S. Wolff, Radiation genetics, Annual Review of Genetics 1 (1971), p. 221.

Zonneveld et al., $1989<$ F. W. Zonneveld, C. F. Spoor, and J. Wind, The use of computed tomography in the study of the internal morphology of hominid fossils, Medicamundi 34 (1989), pp. 117-128. 